\title{
The Impact Assessment Of Demographic Factors On Faculty Commitment In The Kingdom Of Saudi Arabian Universities
}

\author{
Adnan Iqbal, Prince Sultan University, Saudi Arabia \\ Husam A. Kokash, Prince Sultan University, Saudi Arabia \\ Salem Al-Oun, Al-Albayt University, Jordon
}

\begin{abstract}
Organizational commitment is perceived as an attitude of association to the organization by an employee, which leads to particular job-related behaviors such as work absenteeism, job satisfaction and turnover intensions. Turnover is the ratio of the number of workers that had to be replaced in a given time period to the average number of workers. Employee turnover is affected by job dissatisfaction, errors in employee selection, and poor management. As a performance indicator, turnover should be understood by management and leadership of the company. Turnover in the teaching profession can have important consequences for universities and students, including the financial and time costs of filling positions, disruption of curricular continuity, and difficulty in maintain a cohesive school environment. This study examines the impact assessment of personal factors on organizational commitment which leads to turnover intentions. The results indicated that the universities in KSA are not stipulating effective measure to retain their worthy and highly qualified resources. Some of the preventive actions include management training in order to capture warning of job dissatisfaction and periodic workplace evaluation of satisfaction, an open door policy style of management, and uphold strict hiring standards. In order to keep costs down, a streamline and efficient human resource program is suggested. Furthermore, organizations may gain more by attaching employees, increasing their investments, and enhancing their obligations to fulfill their goals.
\end{abstract}

Keywords: Turnover; satisfaction; performance; universities; Saudi Arabia; Private and Public Universities; Organizational Commitment, Exit interviews

\section{INTRODUCTION}

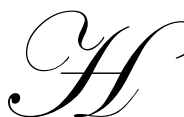

erscovitch and Meyer (2002) defined organizational commitment as the degree to which an employee identifies with the goals and values of the organization and is willing to exert effort to help it succeed. The issue of organizational commitment within both private and public sector organizations has, generally, received significant research focus over the past 25 years. Early researchers of organizational commitment (Becker, 1960; Kanter, 1968) identified that commitment is primarily a function of individual behavior and willingness of individuals to give their energy to the organization through actions and choices over time. In other words, Becker (1960) described commitment as the tendency to engage in consistent lines of activity, such as intent to stay in the organization. Furthermore, employees' commitment to their employers and organizations emerged a great interest to researchers of organizational studies.

It is widely accepted that degree of organizational commitment and job performance are positively correlated (Mowday, Porter, and Dublin, 1974), while tardiness, absenteeism (Steers, 1977) and turnover (Hom, Katerberg, and Hulin, 1979) are inversely related. 


\section{Perspectives of organizational commitment}

Organizational commitment has been researched with two perspectives for analysis. These are Behavioral Perspective and Attitudinal Perspective.

\section{Behavioral Perspective}

Early researchers (Becker, 1960; Angle and Perry, 1983; Alluto, Hrebiniak and Alonso, 1973) have focused on a behavioral definition of commitment. They explained organizational commitment as a binding of the individual to behavioral acts. Becker (1960) argued that an individual acts in a committed manner because previously extraneous situational factors have become agents of influence or 'investment' in the individual's present actions. This theory was later rejected by Ritzer and Trice (1969) and Aranya and Jacobson (1975). However, Angle and Perry (1983) affirmed Becker's Behavioral Perspective. Alutto et al (1973) expanded the Becker's (1960) theory of 'side-bet' 1 and included the notion of the 'investment' in this theory. After the rejection of this theory, researchers focused their attention on the attitudinal commitment.

\section{Attitudinal Perspective}

Mowday, Porter and Steers (1979) Model

Mowday et al (1979) define organizational commitment (Attitudinal Commitment), which has three components: (a) a strong belief in and acceptance of organizational goals and values, (b) a willingness to exert considerable effort on behalf of the organization, and (c) a strong desire to maintain membership in the organization. Research on organizational commitment has been examined primarily in relation to turnover (Ferris and Aranya, 1983; Hom, Katerberg, and Hulin, 1979; Huselid and Day, 1991; Mowday, Steers, and Porter, 1979; O'Reilly and Caldwell, 1980; Steers, 1977; Stumpf and Hartman, 1984; Wiener and Vardi, 1980).

Meyer and Allen (1997) Model

Meyer and Allen (1997) view organizational commitment as a three component concept. The three components in their model are 'Affective', 'Continuous', and 'Normative'. The affective commitment describes the emotional attachment an individual has with the organization, their identification with the goals and values of the organization and the level of their involvement (Zanagro, 2001). Affective commitment is taken as a construct closely related to identification (Bergami and Bagozzi, 2000). Continuance commitment is based on the cost that an employee associates with leaving the organizations, such as reduction in pay, pension, benefits, or facilities (Hrebiniak and Alutto, 1972). Normative commitment is associated with employees' feelings of obligation to continue employment due to the work culture and other socially accepted norms (Weiner and Gechman, 1977). The less common approach to viewing commitment is in terms of obligation. Of the three components least is known about the development of normative commitment (Meyer and Allen, 1997).

Viewing commitment as an affective or emotional attachment to an organization is the most common approach in the literature to studying commitment (Mowday et al, 1979). The present study was delimited to using primarily the attitudinal perspective of commitment and some of the demographic factors in general.

\section{ORGANIZATIONAL COMMITMENT AND TURNOVER INTENTIONS}

The majority of researchers have treated organizational commitment as a dependent variable in their studies (Morrow, 1983 in DeCotiis \& Summers, 1987). For instance, Steers (1977) examined the relationship between work related variables as antecedents of climate (group attitudes, organizational dependability, and personal impact) and organizational commitment. This study was carried out among 382 hospital employees, 119 scientists and engineers.

\footnotetext{
${ }^{1}$ Side-bets are any investments of value made by both parties, that are not related to the job but serve to ensure continued organizational membership by the individual. 
The relationship between organizational commitment and other outcomes has also been examined in developing countries. For instance, Ahmed \& Alvi (1987) surveyed 1116 employees in various organizations of Pakistan. Exchanged-base variables included wage, job, security, union affiliation, Length of service and type of organization. They found that interested work, task identity, peer's friendliness, and authority turned out to be factors that had a significant positive influence on commitment. They also confirmed that any organization which fulfils its workers' psychological needs, along and provides a better working environment enhances their commitment.

Another study was carried out by Khaleque \& Rahman (1987) to measure overall job satisfaction of industrial workers in Bangladesh. This study was designed to 1) measure the overall job satisfaction of industrial workers; 2) determine the influence of some personal factors and job facets on the overall job satisfaction of the workers; and 3) evaluate the perceived importance of some facets on the overall job satisfaction of the workers. They found that some specific aspects of jobs, such as good relations with peers, convenient work scheduling, good working environment, and a job security had stronger influence on job satisfaction and commitment.

Demographic factors such as age, length of service, and education level have been associated with organizational commitment (Abdulla \& Shaw, 1999; Chughtai \& Zafar, 2006; Dodd-McCue \& Wright, 1996; Iqbal, 2010; Luthans, McCaul \& Dodd, 1985; Morrow, 1993; Salami, 2008), however, Mathieu \& Zajac (1990) and Weidmer (2006) in Salami (2008) found that demographic factors were not significant predictor of organizational commitment.

Viewing commitment as an affective or emotional attachment to an organization is the most common approach in the literature to studying commitment (Mowday et al, 1982). The present study was delimited to using primarily the attitudinal perspective of commitment. Present study is an inquiry into the attitude and perception which employees have towards commitment in Kingdom of Saudi Arabian Universities (KSA) and their intentions toward turnover.

Employee's turnover has a number of sole and combined causes depending on a variety of issues dealing with work-related and non-work-related matters dealing, and not just with money issues Bowden (1952). Employees conflicting dissatisfaction may be combined of responsibilities of work, family, community, and personal (Hom and Kinicki, 2001). Employees often leave their jobs for a better job or for reasons unrelated to the job, they may be looking for a better opportunity and not suffer from job dissatisfaction (Noah and Yong-Pin, 2002; Sheehan, 1995).

Job dissatisfaction eventually leads in a progressive manner to the employee leaving the company (Hom and Kinicki, 2001). Hom and Kinicki (2001) discuss that the multiple role employees play at work is stressful and decreases job satisfaction and thus increasing the likelihood of the employee leaving the company. Otherwise, employees use voidance strategy when dissatisfied with their work.

Laser (1980) suggests that that the main causes of turnover are salary issues and shifting values and change in today's work ethics. However, turnover can be attributed to improper selection of personnel, lack of an adequate orientation and training program, and organizational personnel management problems (Noah and Yong-Pin, 2002). In addition, employees have been shown to react favorably, and therefore, stay longer, in positions where they are involved in some level of the decision making process (Magner et at., 1996).

\section{SIGNIFICANCE OF THE STUDY}

Some studies conducted in Arab universities (such as Al-Yahya, 2007) observed a new tendency among university faculty to quit their jobs in their respective institutions and seek employment elsewhere, a phenomenon known in management as employee turnover. Al-Yahya (2007) noted that the result of an increasing rate of turnover, the government accrued great losses because the majority of faculty members had received their graduate degrees (mostly from the United States and Europe) through scholarships awarded by the government. To gauge the satisfaction level among faculty members, for instance, Hakim (1989) (in Al-Yahya (2007)) conducted a study on 378 members at King Abdul Aziz University, the second largest university in Saudi Arabia. He found rigid 
administrative procedures (including stick reliance on seniority) and inadequate opportunities for research and advancement.

In another study on faculty turnover, Al-Meth'heb (1998) (in Al-Yahya (2007)) found that 78 percent of faculty think of leaving the university temporarily (short-term leave to work for another organization) while 20 percent prefer to quit their job permanently. The majority (67 percent) indicated that they prefer to work for the private sector because of their belief that it provides greater opportunities for recognition, self-actualization, and advancement. Respondents also indicated their dissatisfaction was due to the lack of effective use of their capabilities and to centralized decision making regarding resources for research and academic conferences.

Faculty turnover, both real and contemplated, is an issue of importance in the life of the academy. Economics of education measures returns to human investment, as today multiversity and educational complexes are having economic dimensions to sustain resources. High faculty turnover is indicative of a poor work environment and reflects in the loss of experienced employees and established customer relationships. Several studies have also examined the various causes of employee turnover (Darden et al., 1987; Good et al., 1988; Hurley and Estelami, 2007). However, a limited research has attempted to link the employees' commitment and employees' turnover intentions in the service provider performance in general and in KSA universities in particular.

\section{THEORETICAL FRAMEWORK OF THE STUDY}

\section{Demographic Factors}

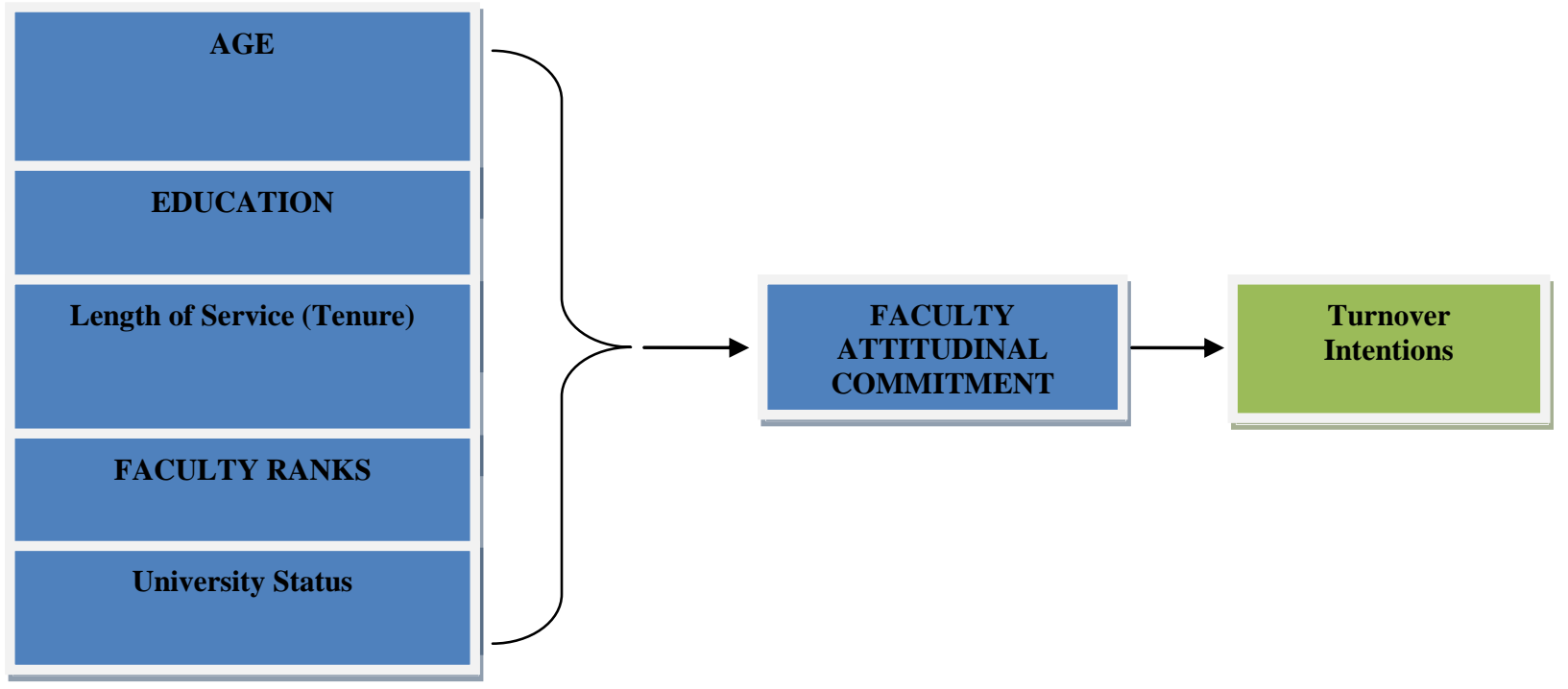

Fig 1: Authors' construct

As shown in Figure 1, the relationship between demographic variables and faculty commitment that leads to faculty turnover intentions. The main question is to investigate the relevant demographic factors associated with Organizational Commitment in KSA universities. Based on the main question, the major hypothesis is formulated as following:

\section{Major Hypothesis:}

The demographic factors (Age, Educational level, Length of service, Job ranks, University status) have no significant impact on faculty commitment in KSA universities.

Through this major hypothesis, minor hypotheses are developed and discussed in the following section. 
A number of empirical studies indicate that demographic variables are relevant to understanding employee turnover intention (Bhuain and Al-Jabri, 1996). Achoui and Mansour (2007) found that the most important studied demographic variables are Age, Length of service and Education. Age has been found to be negatively related to employee turnover tendency (Bhuain and Al-Jabri, 1990). Younger employees have a higher probability of leaving (Achoui and Mansour, 2007). The relationship between education and employee turnover has also been observed, with highly educated employees more likely to leave the organization than less educated employees (Arnold and Feldman, 1982) and some found no relationship between employee turnover and education (Horner, Mobley, Meglino, 1979). Similar to education, length of service is contributing to turnover decision. Employees with long work experience have been found to have low turnover tendency (Gregersen and Black, 1992). However, the effect of demographic factors on the turnover tendency is cultural bound and empirical research on the influence of personal factors on employee turnover tendency in an international context is limited (Naumann, 1993). The preceding discussion stipulates the study of the following research hypotheses.

Age

Some researchers found a significant and positive relationship between age and employees' commitment. For instance, Mathieu \& Zajac (1990) found that age is significantly associated with organizational commitment. Sommer, Bae \& Luthans (1996) confirmed the previous finding and noted that the organizational commitment among Korean employees increases with age. Researchers suggest that older workers are likely to experience higher level of commitment (Abdulla \& Shaw, 1999). This finding may be due to the fact that older people at workplace lower their expectations to more realistic levels and adjust themselves better to their work situations (Newstrom, 2007). Therefore, the following hypothesis is proposed:

$\mathbf{H}_{1}$ : Demographic factor such as Age has no significant impact on faculty commitment in KSA universities.

\section{Level of education}

Level of education is another demographic factor that has been related to organizational commitment. Steers (1977) found that level of education was negatively related to organizational commitment. Similarly, Mathieu \& Zajac's (1990) meta-analysis confirmed this relationship and found that the relationship was significantly stronger but negative for attitudinal commitment. Highly educated individual may have less commitment since they may have other opportunities of employment. So, it is assumed that:

$\mathbf{H}_{2}$ : There is no significant relationship between Demographic factor such as Education and faculty commitment in KSA universities.

Length of service (Tenure)

Commitment is usually stronger among long-term stay employees (Newstrom, 2007). Meyer, Herscovitch \& Topolnytsky (2002) found a significant and positive relationship between organizational commitment and length of service. They further suggest the possibility that the longer a person works in an organization and the older they become their feelings of responsibility for outcomes relevant to them also increases. Salami (2008) also identified a positive and strong relationship between organizational Length of service and organizational commitment. Therefore, the following hypothesis is proposed:

$\mathbf{H}_{3}$ : There is no positive relationship between Demographic factor such as Length of service and faculty commitment in KSA universities.

Addition to this, past research also indicates that employee perceptions are an important factor for predicting organizational commitment. Perception varies a lot from time to time, place to place and person to person (Job ranks). Therefore, following hypotheses are proposed to study employee perceptions.

$\mathbf{H}_{4}$ : There is no positive relationship between demographic factor such as job ranks and faculty commitment in KSA universities 
H5: There is no positive relationship between Status of Universities (private or public) and faculty commitment in KSA universities.

\section{METHOD}

The present study is a relationship based research in that it attempts to establish a correlation between demographic factors (such as Age, Job ranks, Length of service, qualification and university Status) and organizational commitment which leads to Employee turnover at universities in Kingdom of Saudi Arabia.

\section{Measures}

The instrument used in this study is composed of two parts. Part one deals with organizational commitment. The commitment is measured by using Mowday and Steers (1979)'s scale. Mowday et al.'s (1979) Organizational Commitment Questionnaire (OCQ) is used to measure employees' commitment to their organizations. This instrument measures attitudinal commitment, and consists of 15 items (six statements were negative). Examples of these items are: "I am willing to put in a great deal of effort beyond that normally expected in order to help this organization to be successful", "I talk up this organization to my friends as a great organization to work for", "I am extremely glad I chose this organization to work for over others I was considering at the time I joined". A five point scale ranging from 1 (strongly disagree) to 5 (strongly agree) was employed. Scores on the 15 items were averaged to yield a summary, score reflecting organizational commitment.

Part two deals with demographic variables. The data on demographic variables is collected through selfreporting questionnaire, which includes the following items age, education, job ranks, university status (public or private) and length of service.

\section{Procedure}

The questionnaires were distributed through personal contacts and referrals to faculty members in five Saudi universities. This snowball non-probability sampling is thought to be more effective, practical and culturally acceptable in Saudi Arabia than other methods such as telephone or mail surveys (Ben-Bakr, Al-Shammari, Jefri and Prasad, 1994). After couple of reminders and personal visits, 79 questionnaires from five organizations were returned. Of the 125 questionnaires distributed, 65 (52\%) were found to be valid. A review of published social research literature suggests that a response rate of $50 \%$ is considered adequate for analysis and reporting (Babbie, 2007).

\section{RESULTS AND ANALYSIS}

In order to achieve the study objectives and test its hypothesis, the researchers utilized the following statistical methods were applied.

Reliability Analysis: To determine what set of scale items can lead to results that are highly correlated by the results which would go so far as to obtain if another test was applied to measure the same.

Descriptive statistic: To demonstrate the faculty's attributes, attitudes and perceptions which affecting their commitment toward the universities subject to study.

Multiple Regression Analysis: To contrast the hypothesis and to explain and demonstrate the effect of demographics as independent variables on the employee turnover as dependent.

We found that Cronbach Alpha of the items $=0.652$ for all the items, which is statistically accepted as good reliability. Cronbach's Alpha ranges in value from 0 to 1. In general an Alpha equal to or greater than .6 is considered a minimum acceptable level. In order to make sure this analysis is consistent and reliable, we proceeded to eliminate each of scale items, the results obtained after eliminating the items one by one, were showing that the reliability of the scales was not improved sensitively. 


\section{Demographic Factors}

Table 1: Percentage of Demographic factors of faculty

\begin{tabular}{|c|c|c|}
\hline \multicolumn{2}{|l|}{ Factor } & \multirow{2}{*}{$\begin{array}{c}\text { Percentage } \\
21.5\end{array}$} \\
\hline Age & less than30 & \\
\hline & $31-35$ years & 30.8 \\
\hline & $36-40$ years & 20.0 \\
\hline & $41-45$ years & 16.9 \\
\hline & $46-50$ years & 1.5 \\
\hline & $51-55$ years & 4.6 \\
\hline & Missing & 4.6 \\
\hline & Total & 1.0 \\
\hline \multirow[t]{8}{*}{ Faculty Rank } & Professor & 0.0 \\
\hline & Associate Professor & 6.2 \\
\hline & Assistant Professor & 30.8 \\
\hline & Lecturer & 27.7 \\
\hline & Instructor & 4.6 \\
\hline & Other & 27.7 \\
\hline & Missing & 3.1 \\
\hline & Total & 1.0 \\
\hline \multirow[t]{5}{*}{ Length of service in Teaching } & Less than 5 years & 69.2 \\
\hline & 6-10 years & 24.6 \\
\hline & $11-15$ years & 3.1 \\
\hline & Missing & 3.1 \\
\hline & Total & 100.0 \\
\hline \multirow[t]{6}{*}{ Highest Degree } & Other & 3.1 \\
\hline & $\mathrm{PhD}$ & 30.8 \\
\hline & Masters & 43.1 \\
\hline & Bachelor & 20.0 \\
\hline & Missing & 3.1 \\
\hline & Total & 1.0 \\
\hline \multirow[t]{3}{*}{ University Category } & Public & 53.8 \\
\hline & Private & 46.2 \\
\hline & Total & 100.0 \\
\hline \multirow[t]{6}{*}{ University Name } & Imam University & 10.8 \\
\hline & KSU & 20.0 \\
\hline & Yamamah University & 30.8 \\
\hline & Mahad & 26.2 \\
\hline & PSU & 12.3 \\
\hline & Total & 100.0 \\
\hline
\end{tabular}

According to Table 1, respondents were quite evenly spread across the age groups. $21 \%$ respondents were less than 30 years, $31 \%$ respondents had age between 31 to 35 years and $17 \%$ respondents had age range from 46 to 50 years. Generally age group ranges from 28 to 55. About the faculty ranks, the data in Table 1 shows that $6.2 \%$ Associate professors, 31\% Assistant Professors, 28\% lecturers and 4.6\% were instructors, which shows a good representation of the staff. In our data set, $54 \%$ universities were from public sector and $46 \%$ universities were from private sector.

Table 1 also shows the data on education level and length of service. $31 \%$ of the respondents had $\mathrm{PhD}$ degrees and $43 \%$ had Master degrees. The data on the length of the service shows that $69 \%$ employees had less than 5 years of experience. 


\section{Organizational Commitment}

Employees' commitment is viewed as a means of ensuring that employees are loyal to their organizations and their intent to remain in organization. A set of 15 statements were administered and the respondents were asked to indicate the extent to which they agree/disagree with statements regarding their organizational commitment. The data is presented in the Table 2.

Table 2: Mean, Standard deviation and Frequency of organizational Commitment

\begin{tabular}{|l|c|c|c|c|c|c|c|}
\hline \multicolumn{1}{|c|}{ Item } & Mean & $\begin{array}{c}\text { Std. } \\
\text { Deviation }\end{array}$ & SD & D & N & A & SA \\
\hline Great Deal of efforts & 4.23 & .915 & 0 & 7.7 & 9.2 & 35.4 & 47.7 \\
\hline Talk to my friends about this Org. & 3.52 & 1.239 & 13.8 & 6.2 & 9.2 & 55.4 & 15.4 \\
\hline Feel little loyal to this Org. & 2.05 & 1.007 & 38.5 & 27.7 & 24.6 & 9.2 & .0 \\
\hline Accept any job in this Org. & 3.23 & 1.086 & 9.2 & 15.4 & 24.6 & 44.6 & 6.2 \\
\hline My and org. values are same & 3.23 & 1.222 & 10.8 & 16.9 & 26.2 & 30.8 & 15.4 \\
\hline Proud to tell others about my Org. & 3.34 & 1.361 & 16.9 & 9.2 & 16.9 & 36.9 & 20.0 \\
\hline Will accept to other Org. & 3.20 & 1.003 & 3.1 & 23.1 & 33.8 & 30.8 & 9.2 \\
\hline Org. inspires me & 2.86 & 1.184 & 7.7 & 41.5 & 20.0 & 18.5 & 12.3 \\
\hline Little change in my present circumstances & 2.98 & 1.008 & 7.7 & 21.5 & 41.5 & 23.1 & 6.2 \\
\hline Glad to choose this Org. over others & 3.35 & 1.067 & 6.2 & 15.4 & 26.2 & 41.5 & 10.8 \\
\hline No much gain from the Org. & 2.80 & 1.078 & 10.8 & 30.8 & 32.3 & 20.0 & 6.2 \\
\hline Disagree with the polices related to employees & 3.05 & 1.165 & 12.3 & 18.5 & 30.8 & 29.2 & 9.2 \\
\hline Care about the fate of the Org. & 3.52 & 1.174 & 6.2 & 15.4 & 20.0 & 36.9 & 21.5 \\
\hline Best to work with this Org. & 3.00 & 1.358 & 12.3 & 32.3 & 20.0 & 13.8 & 21.5 \\
\hline Definite mistake to work with this Org. & 2.22 & 1.205 & 33.8 & 33.8 & 15.4 & 10.8 & 6.2 \\
\hline
\end{tabular}

Results shown in Table 2 indicate that $83 \%$ of respondents seem to support that a great deal of effort is exerted in their respective organizations. $70 \%$ of respondent believe that they are proud to tell other about their affiliation with their organizations. However, $78 \%$ respondents do not believe it was their mistake to work with their respective organizations.

Table 3: Multiple Regression Analysis

\begin{tabular}{|l|c|c|c|c|c|}
\hline & Sum of Squares & df & Mean Square & F & Sig. \\
\hline Regression & 5.221 & 6 & 0.870 & 5.494 & $.000^{\mathrm{a}}$ \\
\hline Residual & 8.712 & 55 & 0.158 & & \\
\hline Total & 13.933 & 61 & & & \\
\hline
\end{tabular}

$\mathrm{R}=0.612^{\mathrm{a}}$

$\mathrm{R}^{2}=0.375$

Table 3 shows the rejection of the major null hypothesis which consists in there is no significant relationship between demographic factors and faculty's commitment to their universities. The results obtained from the multiple regression analysis demonstrate that $\mathrm{f}$ value is equal to 5.494 with significance level $=0.000$, which means that all the faculties' demographics together explained the variation in commitment toward their universities, where the explanation rate was $R^{2}=0.375$.

Based on the correlation value $\mathrm{R}=0.612$, the relationship between demographics and the commitment is somehow strong and positive.

\begin{tabular}{|c|c|c|c|c|c|}
\hline & $\bar{B}$ & Std Frror & Beta & t & Siq \\
\hline Age & -.031 & .046 & -.086 & -.668 & .507 \\
\hline Faculty Ranks & .077 & .075 & .210 & 1.016 & .314 \\
\hline Length of service in Teaching & .272 & .101 & .305 & 2.698 & .009 \\
\hline Highest Degree & -.291 & .116 & -.483 & -2.507 & .015 \\
\hline University Category & -.132 & .125 & -.139 & -1.051 & .298 \\
\hline
\end{tabular}


Regarding the minor hypothesis for demographics, the results obtained from Table 4 indicate the acceptance of the first minor null hypothesis Demographic factor such as Age has no significant impact on faculty commitment in KSA universities. Where its significance is $=0.507$. This last result is very similar to others obtained from the Table 4 about the fourth and the fifth minor null hypothesis, regarding faculty ranks and university category consequently. Where we found that Demographic factor such as Job Ranks has a significant but positive impact on faculty commitment in KSA universities Sig. $=0.314$ and Status of Universities (private or public) has a significant impact on faculty commitment in KSA universities $\mathrm{Sig}=0.298$. So we accept these two minor null hypotheses.

As in the case of education level and highest degree of faculty and its impact on commitment, we reject the null hypothesis consists that Demographic factor such as Education has a significant but negative impact on faculty commitment in KSA universities, and accept the alternative hypothesis where the result indicates that there is a negative impact $\mathrm{t}=(-2.507)$ and sig. $=0.015$ which means reverse correlate between highest degrees and faculty commitment.

The third minor null hypothesis was accepted and confirmed that Demographic factor such as Length of service has a significant but positive impact on faculty commitment in KSA universities. Where the sig. $=0.009$.

\section{DISCUSSION}

The purpose of this research is to examine the extent to which faculty members at KSA universities are committed to their respective universities. Also, it is intended to find out the impact of the some of the demographic (such as Age, Qualifications, Length of service, University status and Job ranks) on organizational commitment that leads to faculty turnover intentions. The results presented above can be discussed as the following.

The results, in Table 4, from this study indicated that the some of the demographic factors such as length of service is highly significant and positively associated with organizational commitment in KSA universities. This finding is consistent with the finding of number of previous researchers who found length of service is significantly associates with organizational commitment (Steers, 1977; Mathieu and Zajac, 1990; Meyer et al., 2002; Newstrom, 2007; Salami, 2008; Iqbal, 2010). This finding suggests the possibility that the longer a faculty member stays in an organization and the older they become their feelings of responsibility for outcomes relevant to them also increases. Furthermore, the interpretation of positive relationship between length of service and faculty commitment goes back to Becker's (1960) side-bet theory, which considered length of service as personal investments. An increased length of service to an organization increases personal investments such as time, efforts promotion, pay, friendships and position in it; these contributed to the level of commitment and made it more likely that the employee would remain a member of the organization. Long service employees are willing to exert a level of efforts that exceeds what is expected from them to achieve success for their organizations (Al-Kahtani, 2004). Suliman and lles (2000) note that the employee who is affectively attached to his or her organization, values his or her investments in it, and feels a moral obligation to maintain membership, will show higher performance than one who is merely affectively, continuance or normatively committed. Therefore, organizations may gain more by attaching employees, increasing their investments, and enhancing their obligations to fulfill their goals.

In Table 4, Educational level found negatively associated with the organizational commitment, it confirms the previous studies (Mowday et. al., 1982; Glisson \& Durick, 1988; Mathieu \& Zajac, 1990; Iqbal, 2010). This finding implies that less educated faculty are comparatively more likely to be committed to the KSA universities than are highly education faculty. This finding may be due to the fact that the highly educated faculty may have developed higher expectation from their serving organizations that it may not be able to adequately meet (Mowday et. al., 1982). Furthermore, education is an individual investment, which would encourage the individual to seek a better return on investment by searching for better jobs (Al-Kahtani, 2004).

No significant correlation was found between organizational commitment and demographic factor (age), this finding is in line with the work previous researchers (Iqbal, 2010; Weidmer, 2006 in Salami, 2008; Chaughtai \& Zafar, 2006, Suliman and lles, 2000). 


\section{CONCLUSION AND RECOMMENDATIONS}

University leadership (competent authorities) can be regarded as the driving force for the universities on the path of efficiency. They can give the assurance of and commit themselves to modeling the desired behaviors combined with the values that need to be institutionalized. The findings from this study will help the university leadership to identify those employee related issues that can impede productivity at the KSA universities.

The organizational commitment has a significantly positive effect on job performance of university faculty in terms of individual effects of various factors on the job performance of university teachers and lower turnover rates. This argument was further attested by Newstrom (2007). He noted that the organizationally committed employees, in general, will usually have good attendance records, demonstrate a willing adherence to company policies, and have lower turnover rates.

Nevertheless, the major finding of this study is that the educational level found negatively associated with the organizational commitment. This finding may be due to the fact that the highly educated faculty may have developed higher expectation from their serving organizations that it may not be able to adequately meet (Mowday et. al., 1982). Some of the preventive actions include management training in order to capture warning of job dissatisfaction and periodic workplace evaluation of satisfaction, an open door policy style of management, and uphold strict hiring standards (Coleman, 1989). Oberholster (2005) notes that if institutions recognize the value of their faculty, they will go to great lengths to invest in their professional development. This perceived support from the institution may also effectively include non-work related training. In essence, faculty need to sense that the institution is supportive of them and has a genuine concern for both their career development and their personal welfare. In order to keep costs down, a streamlines and efficient human resource program is recommended (White, 1995).

In general, the turnover can have a detrimental effect on an organization and its employees if company management allows it. There are tools to assist in addressing the causes of turnover. Since turnover is often used as a performance indicator, maybe the preventive measures should be as well. It is impossible to eliminate turnover altogether; therefore, management must learn how to deal with it and the effects it has on a company. In addition, management should be better prepared to take the proper actions on anonymous surveys and exit interviews. All efforts should be focused on maintaining employee job satisfaction and managing controllable causes of turnover. Research suggests that there are differences between the reasons for turnover that employees provide in exit interviews and the reasons employees provide in anonymous surveys (Heneman and Judge, 2009). In conclusion, the assessment of the workplace environment is crucial and a regular system to capture and evaluate feedback must be in place in order to maintain a healthy work environment. This study, however, may serve as a foundation for future studies on larger scales with same variables, which in turn could generate strategies to reduce the faculty turnover and to improve the global retention of new faculty members and employees in universities. The present research should be helpful to HR at KSA universities in their faculty recruitment decisions.

\section{LIMITATIONS AND IMPLICATIONS FOR FUTURE RESEARCH}

In this study, faculty participation was voluntary and was conducted at five universities in Riyadh city, Kingdom of Saudi Arabia. So, the findings should be interpreted with caution as the participants were from a particular city of the Kingdom Saudi Arabia and do not represent all faculty members in this country. More studies of on this topic are needed with samples, which are large enough to detect statistically significant associations between the variables under investigation.

Another potential limitation of this study includes the scope of the research. This study aims to explore the relationship between demographic factors and faculty commitment that leads to faculty turnover intentions. Future research also needs to explore the effects of sub-variables, Job ranks (such as Instructor, Lecturer, Assistant professor, Professor) and University status (Public or Private), that were not explored in the current study, which can also directly or indirectly influence the faculty commitment in KSA universities. 


\section{AUTHOR INFORMATION}

Dr. Adnan Iqbal majors in Human Resource Management and is currently an Assistant Professor in the Department of Marketing and Management, College of Business Administration, Prince Sultan University, Riyadh Saudi Arabia.

Dr. Husam A. Kokash majors in Marketing and is currently an Assistant Professor in the Department of Marketing and Management, College of Business Administration, Prince Sultan University, Riyadh Saudi Arabia.

Dr. Salem Al-Oun majors in Marketing and is currently an Associate Professor in College of Business Administration, University of Al-AlBayt, Jordon.

\section{REFERENCES}

1. Abdulla, M. H. A.,and Shaw, J. D. (1999). Personal Factors and organizational commitment: Main and interactive effects in the United Arab. Journal of Managerial Issues, 11 (1):77-93.

2. Achoui, M and Mansour, M (2007). Employee turnover and Retention strategies: Evidence from Saudi companies, International Review of Business Research Paper, 3(3): 1-16

3. Ahmed, S. W., and Alvi, S. A. (1987). Assessing Organizational Commitment in a developing country: Pakistan, A case Study. Human Relations, 40(5): 267-280.

4. Al-Kahtani, M. A (2004). An Assessment of organizational commitment in the Institute of Public Administration in the kingdom of Saudi Arabia: The effects of personal demographics and job-related factors on faculty commitment, Unpublished Doctoral Dissertation, Virginia Commonwealth University.

5. Alluto, J., Hrebiniak, L. and Alonso, R. (1973). On operationalzing the concept of commitment”, Social Forces, 51(4): 448-454

6. Al-Yahya, K (2007). The over-educated, under-utilized public manager: why doesn't human capital development bring desired outcomes?, Academy of Management proceedings

7. Anderson, P. and Meyer, B. D. (1994). The Extent and Consequences of Job Turnover. Brookings Working Papers on Economic Activity,177-236.

8. Angle, H.L. and Perry, J. L. (1983). Organizational Commitment: Individual and Organizational Influence, Work and Occupation, 10(2): 123-146.

9. Aranya, N. and Jacobson, D. (1975). An empirical study of theories of organizational and occupational commitment, Journal of Social Psychology, 97: 15-22

10. Babbie, E (2007). The Practice of Social Research, 11ed, Belmont, CA: Thomson Learning Inc.

11. Becker, H. S (1960). Notes on the concepts of commitment, American Journal of Sociology, 66(1): 32-40

12. Ben-Bakr, K. A, Al-Shammari, I, S., Jefri, O. A., and Prasad, J. N. (1994). Organizational Commitment, Satisfaction and turnover in Saudi organizations: A predictive Study, The Journal of Socio-economics, 23(4):449-456.

13. Bergami, M. and Bagozzi, R. P (2000). Self-categorization, affective commitment and group self-esteem as distinct aspects of social identity in the organization, British Journal of Social Psychology, 39(1): 555-577

14. Bhuian, S. N and Al-Jabri M, I.(1996) Expatriate Turnover Tendencies in Saudi Arabia: An Empirical examination, The International Journal of Organizational Analysis, 4(4): 393-407

15. Bowden, G. T. (1952). The Problem of Employee Turnover. Harvard Business Review, 30 (5):72-82.

16. Chughtai, A., and Zafar, S. (2006). Antecedents and Consequences of Organizational Commitment among Pakistani University Teachers. Applied H.R.M. Research, 11:39-64

17. Coleman, L. G. (1989). Sales Force Turnover has Managers Wondering Why. Marketing News, 23(25): 67.

18. Darden, W.; Hampton, R.; and Boatwright, E. (1987). Investigating Retail Employee Turnover: an Application of Survival Analysis. Journal of Retailing, 63: 69-88.

19. DeCotiis, T. A. and Summers, T. P. (1987). A path-analysis of a model of the antecedents and consequences of organizational commitment, Human Relations, 40(7): 445-470

20. Dodd-McCue, D., Wright, B. (1996). Men, women and attitudinal commitment: The effects of workplace experiences and socialization. Human Relations, 49: 1065-1089

21. Ferris, K. and Aranya, N. (1983). A comparison of two organizational commitment scales, Personnel Psychology, 36(1): 87-98 
22. Glisson, C. A., and Durick, M. (1988). Predictors of job satisfaction and organizational commitment in human service organizations. Administrative Science Quarterly, 33: 61-81

23. Good, L. K.; Sisler, G. F.; and Gentry, J. (1988). Antecedents of Turnover Intentions Among Retail Management Personnel. Journal of Retailing, 64: 295-314.

24. Heneman III, G. H and Judge, T. A (2009). Staffing Organizations, McGraw Hill International Edition

25. Herbiniak, L. G. and Alutto, J. A. (1972). Personal and role related factors in the development of organizational commitment, Administrative Science Quarterly, 17(4): 555-573

26. Herscovitch, L. and Meyer, J.P. (2002). Commitment to organizational change: extension of a threecomponent model, Journal of Applied Psychology, 87: 474-87.

27. Hom, P., Katerberg, R. and Hulin, C. (1979) .Comparative examination of three approaches to the prediction of turnover, Journal of Applied Psychology, 64(1): 280-290

28. Hom, P. W. and Kinicki, A. J. (2001). Toward a Greater Understanding of How Dissatisfaction Drives Employee Turnover, Academy of Management Journal, 44: 975-87

29. Horner, S. O., Mobley, W. H. and Meglino, B. M (1979). An Experimental evaluation of the Effect of realistic job preview on Marine recruit Affect, Intentions and Behavior. Office of Naval Research Arlington VA.

30. Huselid, M. and Day, N. (1991). Organizational commitment, job involvement, and turnover: A substantive and methodological analysis, Journal of Applied Psychology, 76 (3): 380-391

31. Hurley, R. F. and Estelami, H. (2007). An Exploratory Study of Employee Turnover Indicators as Predictors of Customer Satisfaction. Journal of Services Marketing, 21 (3):186-199

32. Iqbal, A. (2010). An Empirical Assessment of Demographic Factors, Organizational Ranks and Organizational Commitment, International Journal of Business and Management, 5(3):16-27

33. Khaleque, A., and Rahman, A. (1987). Perceived importance of Job Facets and overall Job satisfaction of industrial workers. Human Relations, 40(7): 401-416

34. Kanter, R. M (1968). Commitment and social organization: A study of commitment mechanisms in the Utopian communities, American Journal of Sociology, 33: 499-517.

35. Laser, S. A. (1980). Dealing with the Problem of Employee Turnover, Human Resource Management, 19(4):17-21.

36. Luthans, F., McCaul, H. S., and Dodd, N. G. (1985). Organizational commitment: a comparison of American, Japanese, and Korean employees. Academy of Management Journal, 28(2): 213-19

37. Magner, N.; Welker, R.; and Johnson, G. (1996). The Interactive Effects of Participation and Outcome Favourability on Turnover Intentions and Evaluations of Supervisors. Journal of Occupation and Organization Psychology, 6(2).

38. Mathieu , J., and Zajac , D. (1990). A review and meta-analysis of the antecedents, correlates, and consequences of organizational commitment. Psychological Bulletin, 108(2): 171-194

39. Meyer, J. P. and Allen, N. J. (1997). Commitment in the workplace: Theory, Research and Application, Thousand Oaks. CA: Sage Publications

40. Meyer, J., Herscovitch, S., and Topolnytsky, L. (2002). Affective, Continuance, and Normative Commitment to the Organization: A Meta-analysis of Antecedents, Correlates, and Consequences. Journal of Vocational Behaviour, 61:20-52

41. Morrow, P. (1993). The theory and measurement of work commitment. Greenwich: CT JAL

42. Mowday, R. T., Porter, L. W. and Dublin, R. (1974). Unit performance, situational factors and employee attitudes in spatially separated work units, Organizational Behaviour and Human Performance, 12(1): 231248

43. Mowday, R. T., Steers, R. M. and Porter, L.W. (1979). The measurement of organizational commitment, Journal of Vocational Behaviour, 14: 224-247.

44. Mowday, R. T., Porter, L. W., and Steers, R. M. (1982). Employee-organizational linkages: The Psychology of commitment, absenteeism, and turnover, New York: Academic Press

45. Newstrom, J. W. (2007). Organizational Behaviour-Human Behaviour at work (12 ${ }^{\text {th }}$ ed). New York: McGraw Hill International Edition

46. Noah, G. and Yong-Pin, Z. (2002). Managing Learning and Turnover in Employee Staffing. Operations Research, 50 (6):991-1006.

47. Naumann, E. (1993). Antecedents and consequences of satisfaction and commitment among expatriate managers. Group cRc Organization Management, 18: 153-187. 
48. Oberholster, F. R (2005). Faculty Commitment in Higher Education: Implications for Strategic Leadership. Info, 8(1): 15-24

49. O'Reilly, C. and Caldwell, D. (1980). The impact of intrinsic and extrinsic factors on subsequent satisfaction and commitment, Journal of Applied Psychology, 65(3): 559-565

50. Ritzer, G and Trice, H. M. (1969). An empirical study of Howard Becker's Sidebet theory”, Sociological Forces, 47(4):.475-479.

51. Salami, S. O. (2008). Demographic and psychological factors predicting organizational commitment among industrial workers. Anthropologist, 10: 31-38

52. Sheehan, E. P. (1995). Affective Responses to Employee Turnover. Journal of Social Psychology, 135 (1):63-69.

53. Sommer, S., Bae, M., and Luthans, F. (1996). Organizational Commitment across Cultures: The Impact of Antecedents on Korean Employees. Human Relations, 49: 977-993.

54. Steers, R. M. (1977). Antecedents and outcomes of organizational commitment, Administrative Science Quarterly, 22(1): 46-56

55. Stumpf, S. and Hartman, K. (1984). Individual exploration to organizational commitment or withdrawal, Academy of Management Journal, 27(2): 308-329

56. Suliman, A and lles, P. (2000). Is continuance commitment beneficial to organizations? Commitmentperformance relationship: a new look, Journal of Managerial Psychology, 15(5): 407 - 422

57. Weiner, Y. and Gechman, A. S. (1977). Commitment: A behavioural approach to job involvement, Journal of Vocational Behaviour, 10(1): 47-52

58. White, G.L. (1995). Employee Turnover: The Hidden Drain on Profits. HR Focus, 72 (1):15-17.

59. Zanagro, G. A. (2001). Organizational Commitment: A concept analysis, Nursing forum, 36(2):1-14 


\section{NOTES}

